treatment with carbimazole, this being decided on a random basis. Patients pretreated with carbimazole were given the drug for a period of two to four months; administration was stopped at least 48 hours before giving a pretherapeutic test dose of ${ }^{131} \mathrm{I}$. The amount of thyroid tissue and the 24-hour uptake were taken into account in determining the activity which was given to the patient, the therapeutic dose (D) being calculated on the basis of $150 \mu \mathrm{Ci}$ of ${ }^{131} \mathrm{I}$ per gramme of thyroid tissue according to the formula :

$$
\mathrm{D}=\frac{\mathrm{M} \times 150}{1,000} \times \frac{100}{\mathrm{U}} \mathrm{mCi}
$$

where $M=$ the mass of the thyroid in grammes and $U=$ the percentage uptake of ${ }^{131}$ I by the thyroid at 24 hours.

All patients were treated at the above dose level $(150 \mu \mathrm{Ci} / \mathrm{g}$.) except for those estimated to have glands of $70 \mathrm{~g}$. or more, who were treated at a dose level of $300 \mu \mathrm{Ci} / \mathrm{g}$. The size of the gland was estimated by palpation. The interval between stopping treatment with carbimazole and giving the therapeutic dose was from three to five days. A final assessment of the response to a single dose of ${ }^{131}$ I was made one year after treatment.

Effect of Pretreatment with Carbimazole on the Subsequent Response to

\begin{tabular}{|c|c|c|c|c|c|c|}
\hline \multirow{2}{*}{\multicolumn{3}{|c|}{ Treatment }} & \multirow{2}{*}{$\begin{array}{l}\text { No. of } \\
\text { Cases }\end{array}$} & \multicolumn{3}{|c|}{ Response to ${ }^{131}$ I Therapy (\%) } \\
\hline & & & & Euthyroid & Hypothyroid & Toxic \\
\hline $\begin{array}{l}\text { Carbimazole } \\
\text { Nil } \quad .\end{array}$ & $\ddot{x}$ & 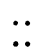 & $\begin{array}{l}83 \\
98\end{array}$ & $\begin{array}{l}63 \\
67\end{array}$ & $\begin{array}{l}14 \\
13\end{array}$ & $\begin{array}{l}23 \\
20\end{array}$ \\
\hline
\end{tabular}

\section{Results}

Pretreatment with carbimazole did not make any significant difference to the subsequent response to ${ }^{131} I$ therapy (see Table). The data suggest that pretreatment with this antithyroid drug does not affect radiosensitivity.

\section{Discussion}

Pretreatment with methylthiouracil and propylthiouracil in thyrotoxicosis modified the response to ${ }^{131} \mathrm{I}$ therapy (Crooks et al., 1960 ; Einhorn and Säterborg, 1962). Thiourea, which contains a sulphydryl radical, and related compounds such as thiouracil have a protective effect on tissues subjected to irradiation (Forssberg, 1950; Mole et al., 1950; Limperos and Mosher, 1950). Other compounds containing a sulphydryl group also have a radioprotective action (Bacq, 1954 ; Gray, 1954). Carbimazole does not contain a sulphydryl group, and our results do not give any indication that pretreatment with this drug modifies the response of thyrotoxic patients to subsequent treatment with ${ }^{131}$ I.

\section{REFERENCES}

Bacq, Z. M. (1954). Acta Radiologica, 41, 47.

Crooks, J., Buchanan, W. W., Wayne, E. J., and MacDonald, E. (1960). British Medical foumal, 1, 151

Einhorn, J., and Säterborg, N. E. (1962). Acta Radiologica, 58, 161.

Forssberg, A. (1950). Acta Radiologica, 33, 296

Gray, L. H. (1954). Acte Radiologica, 41, 63.

Limperos, G., and Mosher, W. A. (1950). Science, 112, 86.

Mole, R. H., Philpot, J. St. L., and Hodges, G. R. V. (1950). Nature, 166, 515 .

\title{
Serological Studies in Infectious Mononucleosis
}

\author{
J. E. BANATVALA,* M.D., м.C.PATH., D.P.H., D.C.H. ; SALLY G. GRYLLS, $†$ M.sc.
}

Sumpras ummary : Serological investigations performed on 27 patients with illnesses resembling infectious mononucleosis showed a significant increase in high antibody titres (more than $1: 40$ ) to EB virus in 11 of the 12 who developed heterophile antibodies. Two of these patients, however, had a significant increase in antibody titre to cytomegalovirus and rubella virus, respectively. Of 15 patient who failed to develop heterophile antibodies, one had a high antibody titre to EB virus, the others generally having undetectable or low antibody titres. The insidious onset of the illness in many patients together with the fact that $\mathrm{EB}$ virus antibodies rose to high titres rapidly reduced the value of this investigation diagnostically.

EB virus antibody was still present in the sera of five patients who bad had well-authenticated heterophileantibody-positive infectious mononucleosis some four to seven years previously. Twenty-seven out of 70 (39\%) healthy nurses had antibody at a level of more than $1: 10$ to EB virus. The presence of EB virus antibody in different population groups appears to be related to such factors as age and socioeconomic status.

\section{Introduction}

Infectious mononucleosis is one of the last common infectious diseases presumed to be of viral aetiology in which a causative agent has still to be clearly established. Attempts to isolate viruses in cell culture have generally been unrewarding, though evidence of infection by cytomegalovirus has been obtained in some patients with illnesses resembling infectious mononucleosis but with no heterophile antibodies (Klemola and Kääriäinen, 1965 ; Klemola et al., 1967). More recent studies conducted by Henle et al. (1968) in Philadelphia and by Niederman et al. (1968) and Evans et al. (1968) at Yale have shown that patients with infectious mononucleosis who develop heterophile antibodies also have significant rises in or already have high antibody titres to EB virus, a herpes-like virus which has been detected in several cell lines from cases of Burkitt's lymphoma (Epstein et al., 1964, 1965 ; Stewart et al., 1965). Unlike heterophile antibodies, antibodies to EB virus persist for long periods, probably indefinitely, and the presence of these antibodies correlates well with immunity to infectious mononucleosis

* Senior Lecturer.

† Leukaemia Fund Research Assistant.

Clinical Virology Department, St. Thomas's Hospital, London S.E.1. 
(Evans et al., 1968). Furthermore, EB virus antigen has been detected in cultures of peripheral leucocytes from some patients with infectious mononucleosis (Diehl et al., 1968). These findings have led both Niederman et al. (1968) and Henle et al. (1968) to postulate that either EB virus or one closely related to it may be the cause of infectious mononucleosis.

Before this conclusion can be finally accepted, however, not only should other laboratories in different parts of the world confirm the serological findings, but attempts should also be made to isolate the virus during the acute phase of illness and to transmit infection to healthy volunteers.

This paper describes serological studies conducted on both heterophile-antibody-positive and negative patients with infectious-mononucleosis-like illnesses, most of whom were nurses. Tests to detect infection by EB virus as well as by other viruses that might cause illnesses-which on clinical grounds resemble infectious mononucleosis-were included. In addition, the incidence of antibody to EB virus occurring in a group of healthy nurses was determined.

\section{Materials and Methods}

Patients Investigated.-Paired serum samples were obtained from 27 patients with infections which on clinical and haematological grounds were consistent with a diagnosis of infectious mononucleosis. Twenty-six patients were nurses aged 18 to 25 , but one patient aged 42 was a member of the hospital medical staff. The first serum sample was taken during the acute phase of the illness, and the second at intervals varying from the 11 th to the 320 th day after the onset. Antibody titres to EB virus as well as to the other antigens listed below were determined in all these patients. In addition, serum samples from five persons who had had well-documented infectious mononucleosis associated with heterophile antibodies some four to seven years previously were tested for antibodies to EB virus. Single samples of serum from 70 healthy nurses aged 18 to 30 were screened at a dilution of 1:10 for antibodies to EB virus.

\section{Serology}

$E B$ Virus.-The indirect immunofluorescent technique for detecting EB virus antibodies was used aocording to the method described by Henle and Henle (1966). Coverslip smears of cells from the EB3 line of Burkitt tumour cells (Epstein et al., 1965) were prepared, cells being maintained on an arginine-deficient medium for three to five days before use (Henle et al., 1968). Serum samples were titrated in doubling dilutions from $1: 5$ to $1: 640$, preparations being finally treated with fluoresceinconjugated anti-human IgG globulin (Hyland Laboratories). Preparations were examined with a Reichert microscope fitted with an HBO 200-W mercury vapour lamp.

Rubella.-Antibodies to rubella virus were determined by haemagglutination-inhibition tests (Stewart et al., 1967), 8 units of antigen (strain Judith) and a microtitre apparatus being used.

Other Antigens.-Antibodies to cytomegalovirus, adenovirus, influenza A, parainfluenza I virus, respiratory syncytial virus, Mycoplasma pneumoniae, and Rickettsia burnetii were determined by complement fixation tests, with two exact units of complement, a microtitre apparatus, and overnight fixation at $4^{\circ} \mathrm{C}$.

Heterophile Antibodies (anti-sheep-cell agglutinins).Heterophile antibodies were determined and the results interpreted according to the method described by Dacie and Lewis (1963).

\section{Results}

The Table shows the principal clinical features and antibody titres to EB virus among those patients with infectious mononucleosis who developed heterophile antibodies. Of 12 patients in this group three had significant (fourfold or greater) rises in antibody titre, two had twofold rises, and all but one of the remainder titres of $1: 40$ or greater in both serum samples. The

Clinical and Serological Features in Heterophile-antibody-positive Patients with Infectious Mononucleosis

\begin{tabular}{|c|c|c|c|c|c|c|c|c|c|c|c|}
\hline \multirow[b]{2}{*}{$\begin{array}{l}\dot{0} \\
Z \\
\dot{d} \\
\tilde{J}\end{array}$} & \multicolumn{4}{|c|}{ Serum I } & \multicolumn{2}{|c|}{ Serum II } & \multicolumn{5}{|c|}{ Clinical Features } \\
\hline & 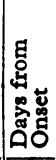 & 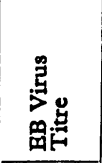 & 实 & 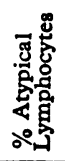 & 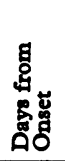 & 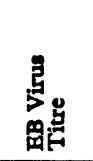 & 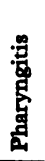 & 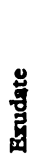 & 勇 & 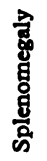 & 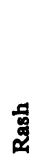 \\
\hline $\begin{array}{c}1 \\
2+ \\
3 \ddagger \\
4 \\
5 \\
6 \\
7 \\
8 \\
9 \\
10 \\
11 \\
12\end{array}$ & \begin{tabular}{|r|}
8 \\
6 \\
9 \\
14 \\
21 \\
4 \\
11 \\
21 \\
4 \\
7 \\
6 \\
14
\end{tabular} & $\begin{array}{r:l}1 & 10 \\
<1 & 5 \\
1 & 10 \\
1 & 160 \\
1 & : 80 \\
1 & \vdots 160 \\
1 & : 160 \\
1 & : 80 \\
1 & : 80 \\
1 & : 40 \\
1 & : 80 \\
1 & : 10\end{array}$ & $\begin{array}{l:l}1 & 320 \\
1 & 640 \\
1 & 320 \\
1 & 1,280 \\
1 & 80 \\
1 & 160 \\
1 & 1,280 \\
1 & 160 \\
1 & 2,560 \\
1 & 604 \\
1 & 320 \\
1 & 80\end{array}$ & $\begin{array}{l}10 \\
59 \\
44 \\
15 \\
4 \\
23 \\
14 \\
35 \\
21 \\
40 \\
20 \\
30\end{array}$ & $\begin{array}{r}52 \\
34 \\
33 \\
44 \\
90 \\
11 \\
78 \\
147 \\
135 \\
47 \\
48 \\
46\end{array}$ & $\begin{array}{l:l}1 & 40 \\
1 & : 80 \\
1 & : 80 \\
1 & 160 \\
1 & : 80 \\
1 & : 160 \\
1 & : 160 \\
1 & : 160 \\
1 & : 160 \\
1 & : 40 \\
1 & : 80 \\
1 & : 10\end{array}$ & $\begin{array}{l}+ \\
+ \\
+ \\
+ \\
+ \\
+ \\
+ \\
+ \\
+ \\
+ \\
+ \\
+\end{array}$ & $\begin{array}{l}\bar{t} \\
\pm \\
\pm \\
\bar{t} \\
\pm \\
\bar{t} \\
\bar{t}\end{array}$ & $\begin{array}{l}+ \\
+ \\
+ \\
+ \\
+ \\
+ \\
+ \\
+ \\
+ \\
+ \\
+ \\
+\end{array}$ & $\begin{array}{l}\bar{z} \\
\bar{z} \\
\overline{ \pm} \\
\pm \\
= \\
\bar{t} \\
+\end{array}$ & $\begin{array}{l}\bar{z} \\
\bar{z} \\
\bar{z} \\
\bar{z} \\
\bar{z} \\
\bar{z}\end{array}$ \\
\hline
\end{tabular}

* Heterophile antibody titre; guinea-pig adsorbed.

+ Concomitant rise in antibody titre by haemagglutination inhibition test to rubella $1: 32-1: 128$

₹ Concomitant rise in antibody titre by complement fixation test to cytomegalo-

geometric mean titre of convalescent phase sera in this group was $1: 80$. The height of the EB virus antibody titre did not necessarily relate to the severity of the illness; nor was there a correlation between levels of heterophile and EB virus antibodies. One patient (Case 12), bowever, a doctor aged 42, though he presented with a typical infectious-mononucleosislike illness with exudative pharyngitis, lymphadenopathy, and splenomegaly, had antibody titres of $1: 10$ in sera obtained 14, 46 , and 76 days after the onset of symptoms. Immunoglobulin studies conducted on these samples showed that levels of total IgG, IgA, and $\operatorname{IgM}$ were within normal limits.

Antibody titres appeared to reach their peak levels at varying intervals after the onset of symptoms. Despite the fact that serum samples were obtained on the fourth and sixth days after the onset of symptoms in three cases (Nos. 6, 9, and 11), antibody titres had already reached high levels $(1: 80-1: 160)$. High titres were maintained for periods up to 147 days. Nevertheless, the three patients (Cases 1, 2, and 3) who showed significant rises in antibody titre had low titres during their acute phase, these serum samples being obtained on the sixth to ninth days after the onset of symptoms. Two of these patients (Cases 2 and 3) may possibly have had double infections, since they also showed serological evidence of infection by cytomegalovirus $(1: 20-1: 80)$ and by rubella virus (1:32$1: 128$ ), respectively. Sucrose density gradient studies conducted on patients with rubella have shown that specific rubella IgM globulins can be detected consistently within three weeks from the onset of symptoms (Best, Banatvala, and Watson, 1969). Though haemagglutination-inhibition tests showed that one patient (Case 2) had developed a rise in antibody titre to rubella virus haemagglutination-inhibition tests from $1: 32$ to $1: 128$, no rubella-specific IgM could be detected in a serum sample obtained six days after the onset of the illness. - This suggested that no primary antigenic stimulus by this virus had occurred, and that the rise in antibody titre to rubella virus therefore probably represented a non-specific anamnestic response to infectious mononucleosis. The $\mathbf{E B}$ virus antibody titres of five patients who had had infectious mononucleosis four to seven years previously persisted at levels varying from $1: 20$ to $1: 80$.

Of 15 patients who failed to develop heterophile antibodies but in whom the clinical and haematological findings were consistent with a diagnosis of infectious mononucleosis, three had no detectable antibody and all but one of the remainder had titres between $1: 5$ and $1: 40$, these results presumably being due to previous infection by EB virus. Among the patients in 
this group there were no significant rises in antibody titre to $\mathrm{EB}$ virus or to any of the other antigens tested; the geometric mean titre of convalescent phase serum samples to $\mathrm{EB}$ virus was $1: 20$. One patient in this group, however, developed symptoms nine days after Case 5 (see Table) with whom she shared a flat. Though hetenophile antibodies were not detected in a serum sample obtained four days after the onset of symptoms, the patient already had an antibody titre of $1: 160$ to EB virus at this time.

When the level of immunity among healthy nurses was determined it was found that 27 out of $70(39 \%)$ had no antibodies. The sensitivity of our indirect immunofluorescent technique for detecting antibodies to EB virus in patients with infectious mononucleosis compared favourably to that of Dr. Henle in Philadelphia, for when serum samples from five patients in this series with varying antibody titres to $E B$ virus were tested in both laboratories similar titres were obtained.

\section{Discussion}

These results show that the patients with infectious mononucleosis who develop heterophile antibodies have rising or high antibody titres to EB virus, and that these titres persist for a long period, whereas those who have no heterophile antibodies generally have undetectable or low antibody titres. These results support those of Henle et al. (1968), who obtained similar results in 42 patients with infectious mononucleosis, and of Niederman et al. (1968), who detected significant rises in antibody titre in 29 Yale students. In the latter study, however, the first serum sample was obtained when students entered the university as freshmen-rather than in the acute phase of the illness-in the expectation that such samples would prove valuable as a baseline for future serological studies. The Henles found that antibody titres were often high in acute phase specimens (Niederman et al., 1968). It follows, therefore, that unless pre-illness serum samples were available in most cases it would not be possible to show rises in titre.

It is difficult to explain why one patient (Case 12) in our series, though he had typical infectious mononucleosis with high-titre heterophile antibodies and many atypical lymphocytes, had only very low EB virus antibody titres $(1: 10)$, the final serum sample being taken as late as the 76th day from onset. Though there have been occasional reports of patients developing antibodies to EB virus rather later than usualfor example, three weeks after onset-all patients so far studied by Dr. Henle (personal communication) have developed EB virus antibodies to a level of $>1: 40$. Nevertheless, Evans et al. (1968), in a study of 135 patients with heterophileantibody-positive infectious mononucleosis, reported one patient who developed only a very weakly positive EB virus antibody titre.

In some cases in our series infectious mononucleosis developed insidiously, so that by the time patients presented for virological investigation many days had already passed since the onset of symptoms, whereas in others EB virus antibodies rose to a high level early in the course of the disease. These factors reduced the value of the test diagnostically. Though Evans et al. (1968) regard a level of more than 80 as suggestive of recent or current infection, in the absence of a significant rise in antibody titre, our studies show that it cannot be conclusively determined in the individual case whether antibodies result from current or past infection; indeed, three of the five patients in our series with well-documented heterophileantibody-positive infectious mononucleosis which occurred four to seven years previously still had titres of $1: 80$.

Evans et al. (1968) have shown that a small proportion of patients who fail to develop heterophile antibodies may develop high titres to EB virus, suggesting that they are true cases of infectious mononucleosis. One patient in our series did not develop heterophile antibodies but had a high antibody titre to $\mathrm{EB}$ virus $(1: 160)$. Since she shared a flat with Case 5 it is very likely that she had infectious mononucleosis.

The presence of antibodies to EB virus in different population groups appears to be related to such factors as age and socio-economic status. Thus Henle and Henle (1967) found that about $80 \%$ of persons aged 17 or more in Philadelphia in a low socio-economic area had already acquired antibodies. These findings were in contrast to those of Niederman et al. (1968), who found $\mathrm{EB}$ virus antibodies present in only $24 \%$ of Yale freshmen. In our series $61 \%$ of apparently healthy nurses had EB virus antibodies, a somewhat similar figure $(58 \%)$ being obtained by Dr. M. S. Pereira (personal communication) in a study of students at a teachers' training college in England. Our figure may well have been lower if serum samples had been obtained only from those nurses who had recently started their training - that is, at a time before they had an opportunity of contracting many of the common infectious agents which are particularly likely to infect groups of young adults living in institutional communities.

We are particularly grateful to Dr. W. Henle (Philadelphia) for his advice and encouragement, to Drs. Therese Vanier and $H$. E. Webb (St. Thomas's Hospital) for their co-operation, to Dr. G. T. Scott (St. Thomas's Hospital) for his serum immunoglobulin estimations, and to Dr. C. M. Bradstreet (Central Public Health Laboratories, Colindale) for complement-fixing antigens.

This work was supported by grants from the Endowment Funds of St. Thomas's Hospital and the Leukaemia Research Fund.

\section{REFERENCES}

Best, J. M., Banatvala, J. E., and Watson, D. (1969). Lancet, 2, 65.

Dacie, J. V., and Lewis, S. M. (1963). Practical Haematology, 3rd ed., p. 410." London, Churchill.

Diehl, V., Henle, G., Henle, W., and Kohn, G. (1968). Fournal of Virology, 2, 663 .

Epstein, M. A., Achong, B. G., and Barr, Y. M. (1964). Lancet, 1, 702.

Epstein, M. A., Barr, Y. M., and Achong, B. G. (1965). Wistar Institute of Anatomy and Biology Symposium Monograph, No. 4, p. 69.

Evans, A. S., Niederman, J. C., and McCollum, R. W. (1968). New England Fournal of Medicine, 279, 1121.

Henle, G., and Henle, W. (1966). Fournal of Bacteriology, 91, 1248.

Henle, G., and Henle, W. (1967). Cancer Research, 27, 2442.

Henle, G., Henle, W., and Diehl, V. (1968). Proceedings of the National Academy of Sciences, 59, 94.

Klemola, E., and Kääriäinen, L. (1965). British Medical fournal, 2, 1099.

Klemola, E., Kääriäinen, L., Von Essen, R., Haltia, K., Koivuniemi, A., and Von Bonsdorf, C. H. (1967). Acta Medica Scandinavica, 182, 311 .

Niederman, J. C., McCollum, R. W., Henle, G., and Henle, W. (1968). fournal of the American Medical Association, 203, 205.

Stewart, S. E., Lovelace, E., Whang, J. J., and Ngu, V. A. (1965). fournal of the National Cancer Institute, 34, 319.

Stewart, G. L., Parkman, P. D., Hopps, H. E., Douglas, R. D., Hamilton, J. P., and Meyer, H. M. (1967). New England fournal of Medicine, 276, 554. 